\title{
Novel Aerobactin Receptor in Klebsiella pneumoniae
}

\author{
By PAUL WILLIAMS, ${ }^{*}$ MARK A. SMITH, ${ }^{1}$ PAULINE STEVENSON, ${ }^{2}$ \\ ELWYN GRIFFITHS ${ }^{2}$ AND JUAN M. T. TOMAS ${ }^{3}$ \\ ${ }^{1}$ Department of Pharmaceutical Sciences, University of Nottingham, Nottingham NG7 2RD, UK \\ ${ }^{2}$ National Institute for Biological Standards and Control, South Mimms, Potters Bar, \\ Herts EN6 $3 Q G, U K$ \\ ${ }^{3}$ Department of Microbiology, University of Barcelona 08071, Barcelona, Spain
}

(Received 19 June 1989; revised 11 September 1989; accepted 15 September 1989)

\begin{abstract}
Several Klebsiella pneumoniae strains which produced enterochelin but not aerobactin were nevertheless sensitive to cloacin DF13. In contrast, a strain of serotype K1:O1 which produced both siderophores was cloacin-resistant. Loss by mutation of the $\mathrm{O} 1$ but not $\mathrm{K} 1$ antigen rendered this strain cloacin-sensitive, indicating that the $\mathrm{O} 1$ antigen prevented access of cloacin to the cloacin/aerobactin receptor. Unlike the $\mathrm{K} 1: \mathrm{Ol}$ strain, the aerobactin-negative strains failed to hybridize in a colony blot assay with an aerobactin receptor gene probe prepared from pColVK30. However, antisera raised against the $74 \mathrm{kDa}$ pColV-K30 aerobactin receptor cross-reacted with a $76 \mathrm{kDa}$ outer-membrane protein in each $K$. pneumoniae strain. In addition to the $76 \mathrm{kDa}$ protein, the $\mathrm{K} 1: \mathrm{Ol}$ strain also produced a strongly cross-reacting $74 \mathrm{kDa}$ protein. To determine whether these aerobactin-negative strains could use aerobactin, mutants unable to synthesize siderophores were isolated. Aerobactin promoted the growth of these mutants in iron-deficient media. The evidence presented suggests that some $K$. pneumoniae strains produce an aerobactin iron-uptake system without apparent production of aerobactin and which is probably based on a $76 \mathrm{kDa}$ receptor, the gene for which does not hybridize with aerobactin receptor gene encoded on pColV-K30.
\end{abstract}

\section{INTRODUCTION}

In response to iron deprivation, many Gram-negative bacteria derepress high-affinity ironsequestering systems based on low-molecular-mass iron-chelating agents (siderophores) and their corresponding outer membrane (OM) receptor proteins (Griffiths. 1987; Neilands, 1981, 1982). Since iron is required for the growth of most pathogenic bacteria, such systems contribute to virulence by enabling the bacterium to sequester transferrin- and lactoferrin-bound iron in body fluids and secretions (Bullen \& Griffiths, 1987; Williams, 1988).

In Escherichia coli, two complete high-affinity iron-sequestering mechanisms have been described. These are based on enterochelin (enterobactin), a phenolate-type siderophore, and aerobactin, a hydroxamate-type siderophore (Griffiths, 1987; Bagg \& Neilands, 1987). The plasmid-encoded ColV-K30 aerobactin-mediated iron-uptake system makes a significant contribution to the virulence of invasive E. coli strains (Williams, 1979; Warner et al., 1981) although the selective advantage it confers over strains already producing enterochelin is not fully understood. The superiority of aerobactin over enterochelin in body fluids may, however, reside in its greater efficiency in sequestering transferrin-bound iron in body fluids (Konopka $e t$ al., 1982; Williams \& Carbonetti, 1986) and in its repeated re-use by the bacterial cell (Braun $e t$ al., 1984; Williams \& Carbonetti, 1986).

Abbreviations: CAS-agar, chrome azurol S/hexadecyltrimethylammonium bromide agar; EDDA, ethylenediamine-di-(o-hydroxyphenylacetic acid); Fe-SSM, iron-depleted simple salts medium; FE + SSM, ironsufficient simple salts medium; OM, outer membrane; TSB, trypticase soy broth. 
The aerobactin iron-uptake systems initially described in $E$. coli were plasmid-encoded (Williams, 1979). However, they are chromosomally encoded in many E. coli K1 strains responsible for human neonatal infections (Valvano et al., 1986). Both plasmid- and chromosomally-encoded aerobactin iron-uptake systems have also been described in Enterobacter, Citrobacter, Proteus, Morganella, Serratia, Shigella, Salmonella and Yersinia (Krone et al., 1985; Waters \& Crosa, 1988; Cercenado et al., 1986; Martinez et al., 1987; Payne, 1980; Griffiths et al., 1985; Colonna et al., 1985; Stuart et al., 1986). In Klebsiella pneumoniae, the presence of a large conjugative plasmid encoding aerobactin production has been reported to correlate, in part, with the virulence of several K1 and K2 serotype strains (Nassif \& Sansonetti, 1986).

The aerobactin gene cluster in pColV-K30 has been reported to consist of an operon containing five genes in the order (iucABCD iutA), four of which (iucABCD) are involved in aerobactin biosynthesis (Carbonetti \& Williams, 1984; Bagg \& Neilands, 1987). The fifth gene (iut $A$ ) encodes a $74 \mathrm{kDa} O M$ protein which functions as the receptor for ferric-aerobactin (Carbonetti \& Williams, 1984; Bagg \& Neilands, 1987). In some enteroinvasive $E$. coli strains (Griffiths et al., 1985; Marolda et al., 1987), in Shigella flexneri (Griffiths et al., 1985) and in Klebsiella edwardsii (Krone et al., 1985) the apparent molecular mass of the receptor appears to be $76 \mathrm{kDa}$ whilst that of Enterobacter cloacae is $85 \mathrm{kDa}$ (Krone et al., 1985). The aerobactin receptor also functions as the receptor for cloacin DF13 (Van Tiel-Menkveld et al., 1982). This bacteriocin, which is capable of killing susceptible cells, has been used to detect the presence of the ferric-aerobactin receptor in E. coli, in Enterobacter and in Klebsiella (Van Tiel-Menkveld et al., 1982; Krone et al., 1985). However, other bacterial surface structures may impede the access of cloacin to its receptor so that not all aerobactin-producing cells are susceptible (Griffiths, 1987; Carbonetti \& Williams, 1985).

In a recent study, we examined the ability of Klebsiella species isolated from a variety of infection sites to express high-affinity iron-uptake systems (Williams et al., 1987). In response to iron deprivation, all strains induced between four and six iron-repressible OM proteins in the 70 to $85 \mathrm{kDa}$ range. All of the isolates examined produced enterochelin whilst six strains also made aerobactin (Williams et al., 1987). The present study was prompted by the observation that many of the Klebsiella strains which did not produce aerobactin were nevertheless sensitive to cloacin DF13. In contrast, some aerobactin producers were resistant to this bacteriocin. In this paper, we describe the existence of an aerobactin iron-uptake system, probably based on a $76 \mathrm{kDa}$ OM protein, in Klebsiella pneumoniae strains which do not produce aerobactin. We also report on an aerobactin-producing, cloacin-resistant, $K$. pneumoniae strain, in which the Oantigen component of lipopolysaccharide appears to be responsible for conferring resistance to cloacin. This strain appears to produce two aerobactin receptors, of 74 and $76 \mathrm{kDa}$, respectively.

\section{METHODS}

Bacterial strains and culture media. The $K$. pneumoniae strains and E. coli K12 (pColV-K30) control strain used in this study are listed in Table 1 . They were routinely cultured in the iron-depleted simple salts medium (Fe-SSM) described previously (Williams et al., 1984) which contains: glucose $35 \mathrm{mM} ; \mathrm{NH}_{4} \mathrm{Cl}, 25 \mathrm{mM} ; \mathrm{KCl}, 1.5 \mathrm{mM} ; \mathrm{NaCl}$, $45.2 \mathrm{mM} ; \mathrm{MgSO}_{4} .7 \mathrm{H}_{2} \mathrm{O}, 0.4 \mathrm{mM}$ and $\mathrm{Na}_{2} \mathrm{HPO}_{4} / \mathrm{NaH}_{2} \mathrm{PO}_{4}, 67 \mathrm{~mm}(\mathrm{pH} \mathrm{7.4)}$. The phosphate buffer was batchincubated with Chelex 100 ion-exchange resin (Bio-Rad) to remove iron. Fe-SSM contains less than $0.5 \mu \mathrm{M}-\mathrm{Fe}^{3+}$ (Lodge et al., 1986). Iron-sufficient simple salts media (Fe $+\mathrm{SSM}$ ) contained $0.02 \mathrm{~mm}-\mathrm{FeSO}_{4}$. Cultures were grown at $37^{\circ} \mathrm{C}$ with shaking and growth determined by measuring the optical density at $470 \mathrm{~nm}\left(\mathrm{OD}_{470}\right)$.

Siderophore detection and isolation. Culture supernatants were assayed for the production of enterochelin and aerobactin by the chemical assays of Arnow (1937) and Arnold \& Viswanatha (1983), respectively. The results were confirmed by bioassay using $E$. coli AN193 (Neilands, 1984) and E. coli LG1522 (Carbonetti \& Williams, $1985)$, respectively, as indicator strains. Aerobactin was isolated and purified from the culture supernatants of $E$. coli K 12 (pColV-K30) by anion-exchange chromatography on Dowex-1 as described by Gibson \& Magrath (1969) followed by solvent extraction with chloroform/phenol $(1: 1, \mathrm{v} / \mathrm{v})$.

Cloacin susceptibility. A crude preparation of cloacin was prepared by exposing a growing culture of Ent. cloacae DF 13 (in nutrient broth) to mitomycin $\mathrm{C}\left(0.5 \mu \mathrm{g} \mathrm{ml}^{-1}\right)$ followed by overnight incubation at $37^{\circ} \mathrm{C}$ with aeration. Cells were removed by centrifugation and the cloacin-containing supernatant sterilized by filtration. $K$. pneumoniae strains were tested for cloacin sensitivity after overnight growth in Fe-SSM by spreading on plates of 
the same medium supplemented with $200 \mu \mathrm{M}$-ethylenediamine-di-(o-hydroxyphenylacetic acid) (EDDA) and solidified by the addition of $1.5 \%(\mathrm{w} / \mathrm{v})$ agar. Samples $(10 \mu \mathrm{l})$ of the crude cloacin preparation were added to wells cut in the agar. Cloacin sensitivity was indicated by a cleared zone around the well.

Isolation of mutants. Mutants derived from $K$. pneumoniae strain DL1 lacking either the $\mathrm{K} 1$ or $\mathrm{Ol}$ or both $\mathrm{K} 1$ and O1 antigens were isolated as described previously (Benedi et al., 1989; Tomas et al., 1986, 1988).

Mutants defective in enterochelin iron-uptake were derived from strain DL44 by mutagenesis with diethyl sulphate as described previously (Tomas et al., 1988). Mutants were selected by their failure to produce an orange halo on blue chrome azurol S/hexadecyltrimethylammonium bromide agar (CAS-agar) prepared, as for $E$. coli strains, according to the method of Schwyn \& Neilands (1987). The ability of enterochelin-negative mutants to use aerobactin was examined by spreading a lawn of cells on Fe-SSM agar medium containing $200 \mu \mathrm{M}-\mathrm{EDDA} ; 10 \mu 1$ aerobactin $\left(20 \mu \mathrm{g} \mathrm{ml}^{-1}\right)$ was added to wells cut in the agar, and following overnight incubation at $37^{\circ} \mathrm{C}$, examined for a halo of growth around the well. The growth kinetics of an enterochelin-negative strain in Fe-SSM, Fe + SSM and $\mathrm{Fe}-\mathrm{SSM}$ supplemented with $20 \mu \mathrm{g}$ aerobactin $\mathrm{ml}^{-1}$ were determined by incubating cells at $37^{\circ} \mathrm{C}$ with aeration and measuring $\mathrm{OD}_{470}$.

Detection of aerobactin receptor genes. Each $K$. pneumoniae strain was screened for the presence of genes encoding the aerobactin receptor by using the colony hybridization technique. $E$. coli K12(pColV-K30) was included as a positive control. The aerobactin receptor gene probe was prepared from $\mathrm{pEN} 7$, a recombinant plasmid which carries the aerobactin receptor gene of pColV-K30 (Gross et al., 1985). Plasmid DNA was purified by column chromatography on Sephacryl S-1000 (Bywater et al., 1983) and then digested with restriction endonuclease BglII (Anglian Biotechnology). A 2 kb iutA DNA fragment, separated and purified on low-melting-point agarose (Weislander, 1979), was radiolabelled by random priming with $\left[\alpha-{ }^{32} \mathrm{P}\right] \mathrm{dATP}$ essentially as described by Feinberg \& Vogelstein (1984).

Bacterial cells for probing were grown overnight at $37^{\circ} \mathrm{C}$ on L-agar. Colonies were transferred to hybridization filters (Colony/Plaque Screen Hybridization Transfer Membrane Discs, Dupont); the cells were lysed, and their DNA was denatured and then bound to the filters by exposure to $254 \mathrm{~nm}$ UV light. Pre-hybridization and hybridization of filters was carried out essentially as described by Singh \& Jones (1984) except that the hybridization solution contained $200 \mu \mathrm{g}$ heparin $\mathrm{ml}^{-1}, 2 \%$ (w/v) sodium dodecyl sulphate (SDS) and $50 \%(\mathrm{v} / \mathrm{v}$ ) formamide ( $100 \%$ de-ionized, Sigma). Hybridization was carried out at $42{ }^{\circ} \mathrm{C}$ overnight. The filter discs were then washed once in $2 \times \mathrm{SET} / 2 \%(\mathrm{w} / \mathrm{v})$ SDS at room temperature for $15 \mathrm{~min}$ and then twice in $0.2 \times \mathrm{SET} / 2 \%(\mathrm{w} / \mathrm{v}) \mathrm{SDS}$ at $65^{\circ} \mathrm{C}$ for $15 \mathrm{~min}(1 \times \mathrm{SET}$ contains $0.15 \mathrm{M}-\mathrm{NaCl}$ and $2 \mathrm{~mm}$-EDTA in $30 \mathrm{~mm}$-Tris/ $\mathrm{HCl}, \mathrm{pH} 7 \cdot 4)$. Discs were exposed to $\mathrm{X}$-ray film overnight at room temperature.

Preparation and electrophoresis of outer membranes. Klebsiella and E. coli OMs were isolated using $2 \%(\mathrm{w} / \mathrm{v})$ sodium $N$-lauroyl sarcosinate (Sarkosyl) as described previously (Williams et al., 1984). OM proteins were separated by SDS-polyacrylamide gel electrophoresis (SDS-PAGE) as described previously on $10 \%$ gels. After electrophoresis, gels were fixed and stained with Coomassie brilliant blue, and photographed or used for immunoblotting.

Preparation of antiserum against the $74 \mathrm{kDa}$ aerobactin receptor protein. The aerobactin receptor protein was isolated from the OM of the cir-negative $E$. coli strain B2B 1022(pABN1) by preparative SDS-PAGE essentially as described by Chart \& Griffiths (1985) except that membranes were solubilized by heating at $66^{\circ} \mathrm{C}$ for $30 \mathrm{~min}$ in Tris/ $\mathrm{HCl}$ buffer $(0.06 \mathrm{M}, \mathrm{pH} 6.8)$ containing $2 \%(\mathrm{w} / \mathrm{v}) \mathrm{SDS}, 10 \%(\mathrm{v} / \mathrm{v})$ glycerol and $0.001 \%$ bromophenol blue. The antiserum was raised in a female Dutch rabbit using three injections of receptor protein given subcutaneously in Freund's incomplete adjuvant at intervals of three weeks. Thirteen days after the third injection, the rabbit was bled and serum prepared. Material obtained from three gels was combined for each injection.

Immunoblotting. OM proteins resolved by SDS-PAGE were transferred to nitrocellulose by electrophoretic blotting (Towbin et al., 1979). After transfer, the aerobactin receptor was detected by sequential treatment with: $1 \%(\mathrm{w} / \mathrm{v})$ skimmed milk to block unbound sites on the nitrocellulose; rabbit antiserum raised against the $74 \mathrm{kDa}$ pColV-K30 aerobactin receptor; and staphylococcal protein $\mathrm{A}$-horse radish peroxidase conjugate (Sigma). Antigenic sites were visualized with a $25 \mu \mathrm{g} \mathrm{ml}^{-1}$ solution of 4-chloronaphthol containing $0 \cdot 01 \% \mathrm{H}_{2} \mathrm{O}_{2}$. The molecular masses and positions of cross-reacting OM proteins were then confirmed by counter-staining the immunoblots with Ponceau S $(0 \cdot 5 \%)$ in $1 \%(\mathrm{v} / \mathrm{v})$ acetic acid.

\section{RESULTS}

\section{Siderophore production and cloacin sensitivity}

Five encapsulated $K$. pneumoniae strains of serotypes K1, K21, K22, K44 and K66 were examined for siderophore production and cloacin sensitivity. Enterochelin was detected in the culture supernatants of all strains but only one strain (DL1) produced aerobactin as determined by both colorimetric and cross-feeding assays (Table 1). However, whilst all four aerobactin- 


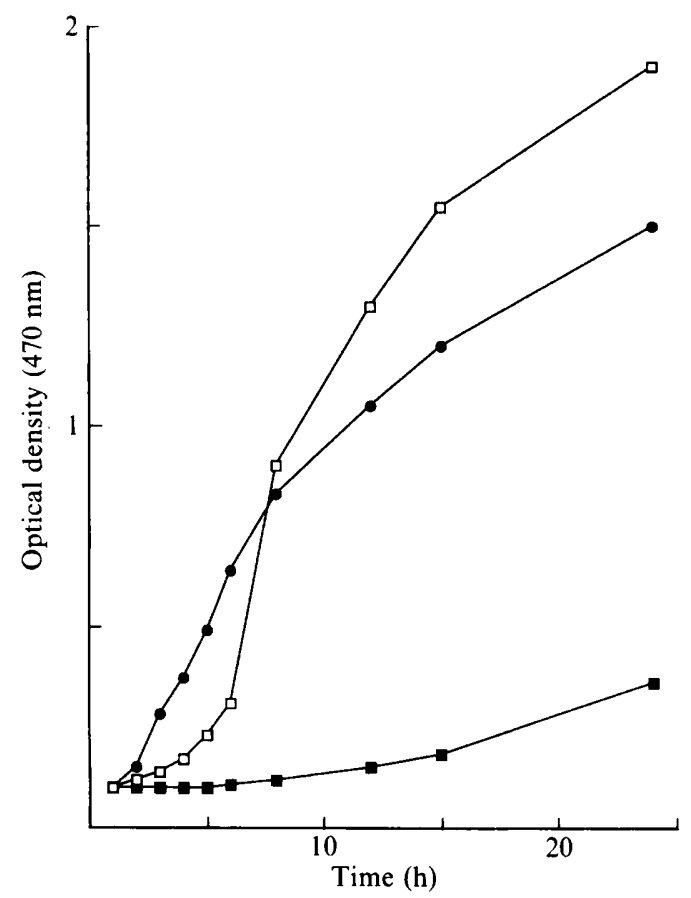

Fig. 1. Growth of $K$. pneumoniae strains DL44 (O) and KN4401 ( $\square$ ) in Fe-SSM, and KN4401 ( $\square$ ) in Fe-SSM supplemented with aerobactin $\left(20 \mu \mathrm{g} \mathrm{ml}^{-1}\right)$.

\section{Table 1. Bacterial strains and properties}

Key: E, enterochelin; A, aerobactin; iutA probe, hybridization with iut $A$ aerobactin receptor gene derived from pColV-K30; +, positive reaction; - , negative reaction; $R$, resistant; $S$, sensitive.

\begin{tabular}{|c|c|c|c|c|c|c|}
\hline \multirow[b]{2}{*}{ K. pneumoniae } & \multirow[b]{2}{*}{ Serotype } & \multirow[b]{2}{*}{ Origin } & \multicolumn{2}{|c|}{ Siderophore produced } & \multirow{2}{*}{$\begin{array}{l}\text { Cloacin } \\
\text { sensitivity }\end{array}$} & \multirow{2}{*}{$\begin{array}{l}\text { iut } A \\
\text { probe }\end{array}$} \\
\hline & & & E & A & & \\
\hline DL1 & $\mathrm{K} 1: \mathrm{O} 1$ & Blood & + & + & $\mathbf{R}$ & + \\
\hline CAPD & K21 : O1 & Peritoneum & + & - & $\mathrm{S}$ & - \\
\hline DL37 & $\mathrm{K} 22: 01$ & Blood & + & - & s & - \\
\hline DL44 & K44:01 & Blood & + & - & $S$ & - \\
\hline $\mathrm{C} 3$ & K66:01 & Environment & + & - & $\mathrm{S}$ & _- \\
\hline KN4401 & \multirow{2}{*}{\multicolumn{2}{|c|}{$\begin{array}{l}\text { Derived from DL44 } \\
\text { Derived from DL44 }\end{array}$}} & - & - & $\mathbf{S}$ & - \\
\hline KN4402 & & & - & - & S & - \\
\hline $\begin{array}{l}\text { E. coli K12 } \\
\text { (pColV-K30) }\end{array}$ & & & + & + & S & + \\
\hline
\end{tabular}

negative strains were sensitive to cloacin DF13, the aerobactin producing strain, DL1, was resistant. To determine whether the K1 capsular polysaccharide or O1 LPS antigen presented a barrier to cloacin adsorption, mutants isogenic with DL1 lacking either the $\mathrm{K} 1$ or the $\mathrm{O} 1$ antigen, or both, were isolated. The $\mathrm{K}^{+}: \mathrm{O}^{-}$and $\mathrm{K}^{-}: \mathrm{O}^{-}$mutants were cloacin-sensitive whilst the $\mathrm{K}^{-}: \mathrm{Ol}$ mutant was cloacin-resistant, suggesting that the $\mathrm{O}$ rather than the $\mathrm{K}$ antigen prevents access of cloacin to the ferric-aerobactin receptor.

Hybridization of the pColV-K30 aerobactin gene probe with $K$. pneumoniae DNA

The pColV-K30 aerobactin gene prepared from plasmid pEN7 hybridized in a colony blot assay only with the aerobactin-producing $K$. pneumoniae strain DL1 (Table 1 ). None of the four cloacin-sensitive aerobactin-negative strains gave a positive reaction with the probe. 


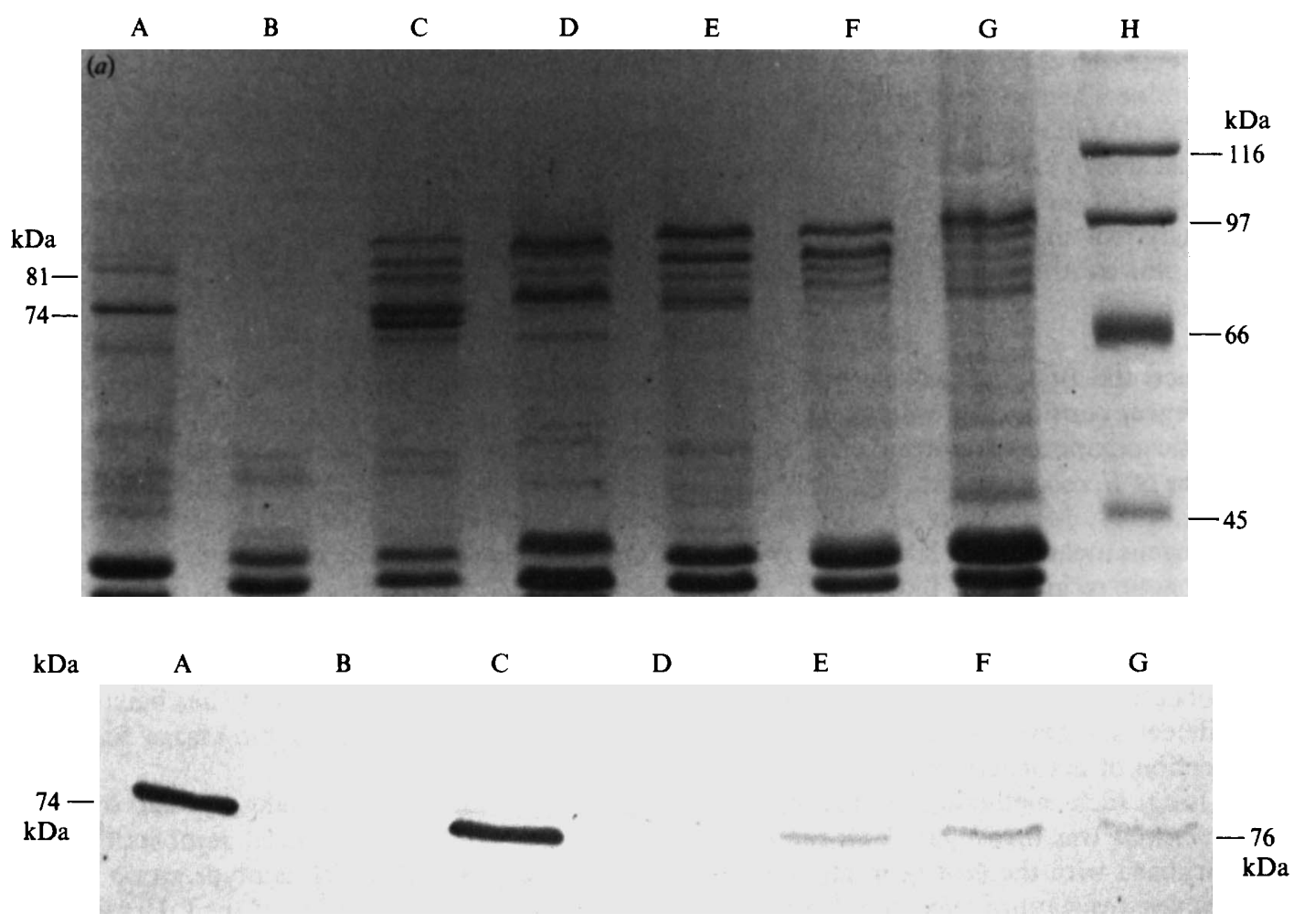

Fig. 2. (a) SDS-PAGE of the OM proteins of $K$. pneumoniae and $E$. coli $\mathrm{K} 12$ (pColV-K30) grown in FeSSM (lanes A and C-G) and of $K$. pneumoniae DL1 (lane B) grown in Fe + SSM. Lane A, E. coli; lane B, DL1; lane C, DL1; lane D, CAPD; lane E, DL37; lane F, DL44; lane G, C3; lane H, molecular mass markers. (b) Immunoblot of the OM proteins of $K$. pneumoniae and $E$. coli $\mathrm{K} 12$ (pColV-K 30) showing the reaction of a polyclonal antiserum raised against the pColV-K30 $74 \mathrm{kDa}$ aerobactin receptor. Lanes are as in $(a)$.

Aerobactin utilization by siderophore-negative $K$. pneumoniae mutants

To determine whether the aerobactin-negative, cloacin-sensitive strains could use aerobactin, strain DL44 was selected and mutagenized with diethyl sulphate to obtain mutants unable to produce enterochelin and thus unable to grow in iron-deficient media. Two mutants, KN4401 and $\mathrm{KN} 4402$, were selected by their failure to produce an orange halo on CAS-agar plates and by their inability to grow on Fe-SSM agar plates containing $200 \mu \mathrm{M}$-EDDA. Fig. 1 shows the growth kinetics of strain DL44 and the isogenic enterochelin-negative mutant $\mathrm{KN} 4401$ in $\mathrm{Fe}-$ SSM. Compared with the parent strain DL44, growth of KN4401 in Fe-SSM was markedly reduced but could be restored upon addition of aerobactin to the medium. Aerobactin also promoted the growth of KN4401 on Fe-SSM/EDDA agar. Growth of both KN4401 and DL44 was also stimulated by addition of excess iron to iron-deficient media (data not shown). Thus the cloacin-sensitive $K$. pneumoniae DL44 which failed to hybridize with the pColV-K30 aerobactin receptor gene probe nevertheless possesses a functional aerobactin iron-uptake system.

\section{Immunochemical characterization of the $K$. pneumoniae aerobactin receptor}

Fig. 2(a) shows an SDS-PAGE gel of the OM proteins of $K$. pneumoniae grown in Fe-SSM compared with those of $E$. coli $\mathrm{K} 12$ (pColV-K30) grown in the same medium. In K. pneumoniae, up to six proteins in the range 70 to $85 \mathrm{kDa}$ were expressed in Fe-SSM (Fig. 2a). Similar results were also obtained when the organism was grown in Trypticase Soy Broth (TSB) containing 
ovotransferrin $\left(1 \mathrm{mg} \mathrm{ml}^{-1}\right)$ (data not shown). Synthesis of these high-molecular-mass proteins was repressed upon addition of excess iron to the medium (Fig. $2 a$, compare lanes B and C). To determine which of these proteins may function as a receptor for aerobactin, proteins separated by SDS-PAGE were transferred to nitrocellulose and probed with a polyclonal antiserum raised against the $74 \mathrm{kDa}$ pColV-K 30 aerobactin receptor (Fig. $2 b$ ). In each $K$. pneumoniae strain, a $76 \mathrm{kDa}$ OM protein was recognized by the antibody. In addition, strain DL1 also produced a strongly reacting $74 \mathrm{kDa}$ protein. Similar results were also obtained with organisms grown in TSB plus ovotransferrin (data not shown).

\section{DISCUSSION}

Since the first indications that the aerobactin iron-uptake system was associated with virulence, considerable efforts have been directed towards elucidating its distribution and genetic organization within virulent enteroinvasive, enteropathogenic and enterotoxigenic strains of E. coli (Griffiths, 1987; Roberts et al., 1986; Carbonetti et al., 1986; Fernandez-Beros et al., 1988; Marolda et al., 1987). This work has been extended to other enterobacterial pathogens including the Klebsiellae (Nassif \& Sansonetti, 1986; Williams et al., 1987). Thus, the aerobactin receptor and biosynthetic genes from pColV-K30 have been cloned into small multicopy plasmids from which receptor and biosynthesis gene probes have been prepared (Bindereif $\&$ Neilands, 1983). These have been used to screen many pathogens for the presence of the aerobactin operon. Alongside these hybridization techniques, cloacin sensitivity has been used to detect synthesis of the aerobactin receptor whilst both chemical and bio-assays for the detection of aerobactin have also been developed.

Using such methodology, the expression of the aerobactin iron-uptake system by $K$. pneumoniae was investigated. Of the five strains examined, only one produced aerobactin and hybridized with the iut $A$ gene probe in a colony-blot assay. This $\mathrm{K} 1: \mathrm{O} 1$ serotype strain was, however, resistant to cloacin but became sensitive upon loss, by mutation, of the $\mathrm{O} 1$ antigen. However, three of four non-aerobactin producing strains which express K21, K22 and K66 capsular polysaccharides were cloacin-sensitive despite possessing the $\mathrm{O} 1$ antigen. Thus the $\mathrm{Ol}$ antigen does not appear to block the access of cloacin to its receptor in all serotypes. Furthermore, other K1:O1 serotype strains (Nassif \& Sansonetti, 1986) have been reported to be cloacin-sensitive. This may be due to differences in the cell-surface distribution of $\mathrm{K}$ and $\mathrm{O}$ antigens or perhaps to differences in the $\mathrm{O}$-antigen chain length in the $\mathrm{K} 1: \mathrm{O} 1$ strain. Further work is required to elucidate the precise mechanism by which cloacin is excluded from its receptor in some but not all $\mathrm{O} 1$ serotype strains.

Despite the failure of the aerobactin-receptor gene probe to hybridize with the aerobactinnegative strains, their cloacin sensitivity indicated that the cells might possess an aerobactin receptor and be capable of using ferric-aerobactin as an iron source. To determine whether the putative aerobactin receptor was functional, mutants of the aerobactin-negative strain DL44, defective in enterochelin biosynthesis, were isolated. Aerobactin stimulated the growth of these mutants on solid media containing EDDA and in Fe-SSM.

$K$. pneumoniae therefore appears capable of scavenging ferric-aerobactin without synthesizing the chelator itself, and thus has a potential selective advantage in infection sites where aerobactin produced by other bacteria could be utilized. In the present study, only four aerobactin-negative strains were examined for aerobactin utilization. Further work is required to determine the distribution of Klebsiella strains expressing a functional aerobactin receptor without apparent aerobactin production. A high incidence of the aerobactin receptor in the absence of aerobactin production has been observed in $E$. coli strains isolated from children with diarrhoea (Fernandez-Beros et al., 1988). In these strains the receptor was located either on a plasmid or in the chromosome but in contrast to the klebsiellae described here, all cloacinsensitive strains hybridized with the pColV-K30 aerobactin gene probe (Fernandez-Beros et al., 1988). In another study of some 500 strains of $E$. coli from human extraintestinal infections, Carbonetti et al. (1986) reported that around $50 \%$ of the strains examined expressed the aerobactin iron-uptake system. Several of these aerobactin-producing strains however, did not hybridize with either the receptor or biosynthesis gene probes. 
In a study of the contribution of the aerobactin system to the virulence of $K$. pneumoniae, Nassif \& Sansonetti (1986) observed one cloacin-sensitive, aerobactin-negative strain. However, in this strain, the aerobactin receptor gene was located on a small plasmid and hybridized with the pColV-K30 probe. In the present study, using moderately stringent conditions (which would be expected to recognize greater than $75 \%$ DNA homology), the probe did not hybridize with the aerobactin-negative $K$. pneumoniae strains. Thus, considerable divergence may exist between this aerobactin receptor gene and that of pColV-K30. To date, examinations of the DNA sequence homology of $E$. coli and Shigella aerobactin systems has revealed considerable homology in the biosynthetic and receptor genes, but differences in the physical maps and divergence in the flanking regions (Marolda et al., 1987). In Enterobacter however, aerobactin systems which show considerable divergence in the biosynthetic genes and/or the receptor gene when compared with that of pColV-K30 have recently been described (Waters \& Crosa, 1988; Crosa et al., 1988).

Despite the lack of hybridization between the pColV-K30 receptor probe and the aerobactinnegative $K$. pneumoniae strains, immunoblotting of OM proteins from $K$. pneumoniae grown in $\mathrm{Fe}-\mathrm{SSM}$ with a rabbit antibody raised against the purified $74 \mathrm{kDa}$ pColV-K30 aerobactinreceptor revealed the presence of an immunologically cross-reacting, iron-repressible OM protein of $76 \mathrm{kDa}$. This reaction was however weaker than that of the pColV-K30 protein. Antigenic homology between the aerobactin receptors of E. coli, Ent. cloacae, K. edwardsii, $S$. flexneri, 'A. aerogenes' and pColV-K30 has also been reported (Krone et al., 1985; Marolda et al., 1987; Waters \& Crosa, 1988). The Ent. cloacae and $K$. edwardsii aerobactin receptors appear to be immunologically more related to each other than to the pColV-K30-encoded receptor protein (Krone et al., 1985). Thus the $76 \mathrm{kDa}$ protein is probably the aerobactin receptor in these aerobactin-negative strains, although further work is required to confirm its functionality. Interestingly, in addition to the $76 \mathrm{kDa} O M$ receptor, a much more strongly reacting $74 \mathrm{kDa}$ protein was also present in the aerobactin-producing, iut $A$-probe-positive $K$. pneumoniae strain DL1. This strain therefore may possess two aerobactin receptors, one of which is much more closely related to that of pColV-K 30 .

Thus, of the six iron-repressible proteins observed in the OM of $K$. pneumoniae DL1, three can now tentatively be assigned a function. The 74 and $76 \mathrm{kDa}$ proteins are probably both aerobactin receptors whilst the $81 \mathrm{kDa}$ is the enterochelin receptor (Williams $e$ t al., 1987). Since $K$. pneumoniae only produces two siderophores, the remaining three proteins may function as receptors for siderophores produced by other micro-organisms. E. coli for example is capable of utilizing fungal siderophores such as ferrichrome and ferrioxamine B (Griffiths, 1987; Neilands, 1982). Exogenously supplied desferrioxamine B has also been reported to be capable of enhancing Klebsiella infections (Khimji \& Miles, 1978) suggesting that this organism may also possess a ferrioxamine B receptor. Further work is currently under way to characterize more fully the iron-repressible $K$. pneumoniae $\mathrm{OM}$ proteins and to determine their genetic localization and organization.

We thank K. Hantke and P. H. Williams for E. coli strains and plasmids, I. Ørskov for serotyping the Klebsiella strains, T. Baldwin and P. Derbyshire for preparation of DNA probes and W. McPheat for helpful discussions.

\section{REFERENCES}

ARnold, L. D. \& Viswanatha, T. (1983). The use of bis(mercaptoacetato-S,O)hydroxoiron(III) complex for the determination of hydroxamates. Journal of Biochemical and Biophysical Methods 8, 307-320.

ARNOW, L. E. (1937). Colorimetric determination of the components of 3,4-dihydroxyphenylalanine-tyrosine mixtures. Journal of Biological Chemistry 228, 531-537.

Bagg, A. \& Neilands, J. B. (1987). Molecular mechanism of regulation of siderophore-mediated iron assimilation. Microbiological Reviews 51, 509518.
Benedi, V. J., Ciurana, B. \& Tomas, J. M. (1989). Isolation and characterization of Klebsiella pneumoniae unencapsulated mutants. Journal of Clinical Microbiology 27, 82-87.

Bindereif, A. \& NeILANDS, J. B. (1983). Cloning of the aerobactin-mediated iron assimilation system of plasmid ColV. Journal of Bacteriology 153, 1111-1113.

Braun, V., Brazel-Faisst, C. \& Schneider, R. (1984). Growth stimulation of Escherichia coli in serum by iron (III) aerobactin. Recycling of aerobactin. FEMS Microbiology Letters 21, 99-103. 
Bullen, J. J. \& GriffithS, E. (1987). Iron and Infection; Molecular, Physiological and Clinical Aspects. New York: John Wiley.

Bywater, M., Bywater, R. \& Hellman, L. (1983). A novel chromatographic procedure for purification of bacterial plasmids. Analytical Biochemistry 132, 219-224.

Carbonetti, N. H. \& Williams, P. H. (1984). A cluster of five genes specifying the aerobactin iron uptake system of plasmid ColV-K30. Infection and Immunity 46, 7-12.

Carbonetti, N. H. \& Williams, P. H. (1985). Detection of synthesis of the hydroxamate siderophore aerobactin by pathogenic isolates of Escherichia coli. In The Virulence of Escherichia coli, Reviews and Methods, pp. 419-424. Edited by M. Sussman. New York: Academic Press.

Carbonetti, N. H., Boonchai, S., Parry, S. H., VAISANEN-RHEN, V., Korhonen, T. \& Williams, P. H. (1986). Aerobactin-mediated iron-uptake by Escherichia coli isolates from human extra-intestinal infections. Infection and Immunity 51, 966-968.

Cercenado, E., Baquero, F., Delgado-Iribarren, A. \& Martinez, J. L. (1986). Epidemiology of aerobactin production in Enterobacteriaceae. Annals de l'Institut Pasteur/Microbiologie 137B, 297-303.

Chart, H. \& Griffiths, E. (1985). Antigenic and molecular homology of the ferric-enterobactin receptor protein of Escherichia coli. Journal of General Microbiology 131, 1503-1509.

Colonna, B., Nicoletti, M., Visca, P. Casalino, M., VAlenti, P. \& Maimone, F. (1985). Composite ISI elements encoding hydroxamate-mediated iron-uptake in Flme plasmids from epidemic Salmonella spp. Journal of Bacteriology 162, 307-316.

Crosa, L. M., Wolf, M. K., Actis, L. A., SandersLOEHR, J. \& CrosA, J. G. (1988). New aerobactinmediated iron uptake system in a septicaemiacausing strain of Enterobacter cloacae. Journal of Bacteriology 170, 5539-5544.

FeinberG, A. P. \& Vogelstein, B. (1984). A technique for radiolabelling DNA restriction endonuclease fragments to high specific activity. Analytical Biochemistry 137, 266-267.

Fernandez-Beros, M. E., Kissel, V. \& Cabello, F. C. (1988). Aerobactin-mediated iron-uptake system in intestinal Escherichia coli. FEMS Microbiology Letters 49, 397-401.

Gibson, F. \& MAGRATH, D. I. (1969). The isolation and characterization of a hydroxamic acid (aerobactin) formed by Aerobacter aerogenes 62-1. Biochimica et biophysica acta 192, 175-184.

GrIFFITHS, E. (1987). The iron-uptake systems of pathogenic bacteria. In Iron and Infection; Molecular, Physiological and Clinical Aspects, pp. 69-137. Edited by J. J. Bullen \& E. Griffiths. New York: John Wiley.

Griffiths, E., Stevenson, P. Hale, T. L. \& Formal, S. B. (1985). Synthesis of aerobactin and a 76,000 dalton iron-regulated outer membrane protein by Escherichia coli-K12-Shigella hybrids and by enteroinvasive strains of Escherichia coli. Infection and Immunity 49, 67-71.

Gross, R., Engelbrecht, F. \& Braun, V. (1985). Identification of the genes and their polypeptide products responsible for aerobactin synthesis by
pColV plasmids. Molecular and General Genetics 201, 204-212.

Khimj, P. L. \& Miles, A. A. (1978). Microbial ironchelators and their action on Klebsiella infections in the skin of guinea-pigs. British Journal of Experimental Pathology 59, 137-147.

KONOPKA, K., BINDEREIF, A. \& NEILANDS, J. B. (1982). Aerobactin-mediated utilization of transferrin iron. Biochemistry 21, 6503-6508.

Krone, W. J. A., Koningstein, G., DE GraAf, F. K. \& OUDEGA, B. (1985). Plasmid-determined cloacin DF13-susceptibility in Enterobacter cloacae and Klebsiella edwardsii; identification of the cloacin DF13/aerobactin outer membrane receptor proteins. Antonie van Leeuwenhoek 51, 203-218.

Lodge, J. M. T., Williams. P. \& Brown, M. R. W. (1986). Influence of growth rate and iron limitation on the expression of outer membrane proteins and enterobactin by Klebsiella pneumoniae grown in continuous culture. Journal of Bacteriology 165, 353-356.

Marolda, C. L., Valvano, M. A., Lawlor, K. M., PAYNe, S. M. \& CROSA, J. H. (1987). Flanking and internal regions of chromosomal genes mediating aerobactin iron uptake systems in enteroinvasive Escherichia coli and Shigella flexneri. Journal of General Microbiology 133, 2269-2278.

Martinez, J. L., Cercenado, E., Baquero, F., Perez-Diaz, J. C. \& Delgado-Iribarren, A. (1987). Incidence of aerobactin production in Gramnegative hospital isolates. FEMS Microbiology Letters 43, 351-353.

NAssif, X. \& SANSONETTI, P. J. (1986). Correlation of the virulence of Klebsiella pneumoniae $\mathrm{K} 1$ and $\mathrm{K} 2$ with the presence of a plasmid encoding aerobactin. Infection and Immunity 54, 603-608.

NeIlandS, J. B. (1981). Microbial iron compounds. Annual Review of Biochemistry 50, 715-731.

NeIlands, J. B. (1982). Microbial envelope proteins related to iron. Annual Review of Microbiology 36, 285-309.

NeILANDS, J. B. (1984). Methodology of siderophores. Structure and Bonding 58, 1-24.

PAYNE, S. M. (1980). Synthesis and utilization of siderophores by Shigella flexneri. Journal of Bacteriology 143, 1420-1424.

Roberts, M., ParthaSarathy, S., Lam-Po-Tang, M. K. L. \& Williams, P. H. (1986). The aerobactin iron-uptake system in enteropathogenic Escherichia coli: evidence for an extinct transposon. FEMS Microbiology Letters 37, 215-219.

SChWYN, B. \& NeIlands, J. B. (1987). Universal chemical assay for the detection and determination of siderophores. Analytical Biochemistry 160, 47-56.

SINGH, L. \& JoNES, K. W. (1984). The use of heparin as a simple cost-effective means of controlling background in nucleic acid hybridization procedures. Nucleic Acids Research 12, 5627-5638.

Stuart, S. J., Prpic, J. K. \& Robins-Browne, R. M. (1986). Production of aerobactin by some species of the genus Yersinia. Journal of Bacteriology 166, 1131-1133.

Tomas, J. M., Benedi, V. J., Ciurana, B. \& Jofre, J. (1986). Role of capsule and O-antigen in resistance of $K$. pneumoniae to serum bactericidal activity. Infection and Immunity 54, 85-89. 
Tomas, J. M., Camprubi, S. \& Williams, P. (1988). Surface exposure of the O-antigen in Klebsiella pneumoniae $\mathrm{K} 1: \mathrm{Ol}$ serotype strains. Microbial Pathogenesis 5, 141-147.

Towbin, H., Staehelin, T. \& Gordon, J. (1979). Electrophoretic transfer of proteins from polyacrylamide gels to nitrocellulose sheets: procedure and some applications. Proceedings of the National Academy of Sciences of the United States of America 76, 4350-4354.

Valvano, M. A., Silver, R. P. \& Crosa, J. H. (1986). Occurrence of chromosome- or plasmid-mediated aerobactin iron transport systems and hemolysin production amongst clonal groups of human invasive strains of Escherichia coli $\mathrm{K} 1$. Infection and Immunity 52, 192-199.

Van Tiel-Menkveld, C. J., MentjoX-Vervuust, J. K., Oudega, B. \& DeGraAF, F. K. (1982) Siderophore production by Enterobacter cloacae and a common receptor protein for the uptake of aerobactin and cloacin DF13. Journal of Bacteriology 150, 490-497.

Warner, P. J., Williams, P. H., Bindereif, A. \& NeIlandS, J. B. (1981). ColV plasmid-specified aerobactin synthesis by invasive strains of Escherichia coli. Infection and Immunity 33, 540-545.

WATERS, V. L. \& Crosa, J. H. (1988). Divergence of the aerobactin iron-uptake systems encoded by plasmids pColV-K30 in Escherichia coli $\mathrm{K} 12$ and
pSMN1 in Aerobacter aerogenes 62-1. Journal of Bacteriology 170, 5153-5160.

WEISLANDER, L. (1979). A simple method to recover intact high molecular weight RNA and DNA after electrophoretic separation in low gelling temperature agarose gels. Analytical Biochemistry 98, 305-309.

WiLliams, P. (1988). Role of the cell envelope in bacterial adaptation to growth in vivo in infections. Biochimie 70, 987-1011.

Williams, P., Brown, M. R. W. \& Lambert, P. A. (1984). Effect of iron deprivation on the production of siderophores and outer membrane proteins in Klebsiella aerogenes. Journal of General Microbiology 130, 2357-2365.

Williams, P., Chart, H., Griffiths, E. \& Stevenson, P. (1987). Expression of high affinity iron uptake systems by clinical isolates of Klebsiella. FEMS Microbiology Letters 44, 407-412.

Williams, P. H. (1979). Novel iron uptake system specified by ColV plasmids; an important component in the virulence of invasive strains of Escherichia coli. Infection and Immunity 26, 925-932.

Williams, P. H. \& Carbonetti, N. H. (1986). Iron, siderophores and the pursuit of virulence: independence of the aerobactin and enterochelin iron uptake systems in Escherichia coli. Infection and Immunity 51, 942-947. 